\title{
Expression and role of TYRO3 and AXL as potential therapeutical targets in leiomyosarcoma
}

Carmela Dantas-Barbosa ${ }^{1}$, Tom Lesluyes ${ }^{2,3}$, François Le Loarer ${ }^{1,4}$, Fréderic Chibon ${ }^{2,5}$, Isabelle Treilleux ${ }^{4}$, Jean-Michel Coindre ${ }^{5}$, Pierre Meeus ${ }^{6}$, Mehdi Brahmi ${ }^{7}$, Olivia Bally ${ }^{7}$, Isabelle Ray-Coquard ${ }^{7}$, Marie-Pierre Sunyach ${ }^{8}$, Axel Le Cesne ${ }^{9}$, Olivier Mir ${ }^{9}$, Sylvie Bonvalot ${ }^{10}$, Maud Toulmonde ${ }^{11}$, Antoine Italiano ${ }^{11}$, Pierre Saintigny ${ }^{1}$, Myriam Jean-Denis ${ }^{12}$, Francoise Ducimetiere ${ }^{4}$, Dominique Ranchere ${ }^{4}$, Hiba El Sayadi ${ }^{1}$, Laurent Alberti ${ }^{1}$ and Jean-Yves Blay ${ }^{\star}, 1,7$

${ }^{1}$ Department of Translational Research \& UMR1052, CRCL, Centre Léon Bérard, 28 Rue Laennec, Lyon 69008, France; ${ }^{2}$ INSERM U1218, Genetics and Biology of Sarcomas, Institut Bergonié, 229 Cours de l'Argone, Bordeaux 33076, France; ${ }^{3}$ University of Bordeaux, 146 Rue Léo Saignat, Bordeaux 33076, France; ${ }^{4}$ Department of Histopathology, Centre Léon Bérard, 28 Rue Laennec, Lyon 69008, France; ${ }^{5}$ Pathology, Institute Bergonié, 229 Cours de I'Argone, Bordeaux 33076, France; ${ }^{6}$ Department of Medical Oncology, Centre Léon Bérard, 28 Rue Laennec, Lyon 69008, France; 'Department of Surgery, Centre Léon Bérard, 28 Rue Laennec, Lyon 69008, France; ${ }^{8}$ Department of Radiation Oncology, Centre Léon Bérard, 28 Rue Laennec, Lyon 69008, France; ${ }^{9}$ Department of Cancer Medicine, Gustave Roussy, 114 Rue Édouard-Vaillant, Villejuif Cedex 94805, France; ${ }^{10}$ Department of Surgery, Institute Curie, PSL Research University, 26 Rue d'Ulm, Paris Cedex 05 75248, France; ${ }^{11}$ Department of Medical Oncology, Institute Bergonié, 229 Cours de l'Argone, Bordeaux 33076, France and ${ }^{12}$ EMS Team, Centre Léon Bérard, 28 rue Laennec, Lyon 69008, France

Background: Leiomyosarcoma (LMS) are 15\% of adult sarcomas and remain seldom curable in metastatic phase. The TAM receptors and their ligands are overexpressed or activated in multiple malignancies, including LMS.

Methods: The TAM receptor and ligand expression was evaluated in LMS cell lines and 358 sarcoma samples by either gene expression or immunohistochemistry. TYRO3 and AXL were knocked down. Crizotinib and foretinib were investigated in vitro.

Results: High expression of TYRO3 and AXL was detected in LMS cell lines. TYRO3 or AXL gene knockdown reduced cell proliferation/colony formation. Crizotinib and foretinib decreased TYRO3 and AXL phosphorylation, apoptosis, G2/arrest and reduced colony formation. Immunohistochemistry performed in 107 sarcomas showed higher expression of TYRO3 and GAS6 in LMS vs other sarcomas and nuclear TYRO3 only in LMS. Microarray gene expression performed in 251 sarcomas revealed significantly higher expression of TYRO3 and GAS6 in LMS than other sarcomas. Leiomyosarcoma patients with high expression of GAS6 or PROS1 present a significantly worse PFS.

Conclusions: Leiomyosarcoma patients, especially those whom develop metastasis, express higher levels of TYRO3 and GAS6. Crizotinib and foretinib showed effective antitumour activity in LMS through TYRO3 and AXL deactivation indicating that clinical trials using TYRO3 and AXL inhibitors are warranted in advanced LMS.

Leiomyosarcoma (LMS) is a malignant tumour of the smooth muscle cells arising from soft tissues or viscera, including the uterine corpus, more rarely the bone (Brewer et al, 2012).
Leiomyosarcoma represent $15 \%$ of adult sarcomas, and gather a heterogeneous group of tumours with different grades and presentation (Ducimetiere et al, 2010). Most LMS are high-grade

*Correspondence: Professor J-Y Blay; E-mail: jean-yves.blay@lyon.unicancer.fr 
sarcomas and exhibit a clinically aggressive behaviour (Clark et al, 2005; Toro et al, 2006). The metastatic relapse rate following local treatment is $\sim 40 \%$ at 5 years (Trent et al, 2007), and cure rate in advanced phase remains very low $(<5 \%)$ with current treatment options, including cytotoxics and targeted agents (Mir et al, 2016; Ratan and Patel, 2016). Cytogenetic analysis and CGH arrays reveal multiple chromosomal rearrangements, with molecular subclassifications emerging (Chibon et al, 2010). However, no strong driver genetic alteration has been identified so far in these diseases (Miettinen, 2014). Cytotoxic and targeted therapies, including pazopanib and trabectedin, prolong progression-free survival (Le Cesne et al, 2005; Benson et al, 2016), and eribulin improved overall survival (Schoffski et al, 2016). However, the median PFS is close 4 months with these different agents in LMS, with few long-term responders, and no key biomarker has been identified to guide the treatment (van der Graaf et al, 2012).

Our previous work identified TYRO3 (TYRO3 protein tyrosine kinase) and AXL (AXL receptor tyrosine kinase) activation in LMS cell lines and tumours (el Sayadi et al, 2013). Both receptors belong to the TAM (TYRO3, AXL and MER - MER proto-oncogene, tyrosine kinase) receptor tyrosine kinase family, which emerged as new potential targets in many oncological diseases, from leukaemia to solid tumours (Graham et al, 2014). The TAM receptors are structurally homologous and share the same vitamin K-dependent ligands: GAS6 (growth arrest-specific 6); and Protein S (Lai and Lemke, 1991). GAS6 is upregulated in response to growth arrest in many different cell types (Hafizi and Dahlback, 2006), and is structurally related to Protein S. Upon ligation, the tyrosine kinase receptors initiate a downstream signalling promoting cell survival, proliferation, migration and adhesion, among other functions (Lemke and Rothlin, 2008). Overexpression of TAM receptors has been identified in a variety of tumours, often with prognostic importance (Graham et al, 2014). AXL, the most widely studied member of these proteins, is implicated in invasiveness and/or metastasis in many of them, including chronic myeloid leukaemia, breast cancer, gliomas, lung, pancreas and prostate carcinoma (Yeh et al, 2011; Suarez et al, 2013). Preclinical data showed that AXL blockade on glioblastoma cells lead to tumour growth reduction and improved survival (Vajkoczy et al, 2006). MERTK is present in almost $50 \%$ of acute lymphoblastic leukaemia (ALL) and in 70$90 \%$ of acute myeloid leukaemia (Pirker et al, 2012; Lee-Sherick et al, 2013), as well as in several other solid tumours (Graham et al, 2014). Though less studied, TYRO3 has been found expressed and activated in melanoma (Zhu et al, 2009) in LMS (el Sayadi et al, 2013) and thyroid cancer (Avilla et al, 2011). TYRO3 is involved in metastasis development, but its level of expression in vivo has not been found correlated to prognosis so far (Graham et al, 2014). Several tyrosine kinase inhibitors, multi-targets or specific AXL/ MERKT inhibitors are currently being developed (Linger et al, 2010; Graham et al, 2014).

To establish whether TYRO3 and AXL contribute to LMS cell proliferation and could represent therapeutic targets, we analysed TYRO3 and AXL function by gene knockdown and expression of TYRO3, AXL and GAS6 in 2 series of 251 and 107 tumour samples of sarcoma patients, including LMS. TYRO3 and AXL inhibitors reduced cell growth, blocked cell cycle and induced apoptosis in LMS cell lines. TYRO3, AXL and ligands GAS6 and PROS1 were found overexpressed in specific sarcomas tumour samples, in particular LMS, and correlated to progression-free survival.

\section{MATERIALS AND METHODS}

Cell lines and reagents. A panel of six LMS tumour cells were used. Five cell lines were established from primary tumours at Institut Bergonié (France): IB112 derived from a LMS of upper limb in a female patient; IB118 is derived from a tumour of the soft part of the head/neck of a man; IB133 from a retroperitoneal tumour in a female patient; IB134 is a uterine LMS; and IB136 derived from a soft tissue tumour of the lower limb in a female patient (Grellety et al, 2015). Cell lines were cultured in RPMI 1640 medium. SK-LMS-1 (ATCC, LGC Standards, Molsheim, France) cell line was cultured in MEM. The human liver carcinoma cell line HepG2 (ATCC) that express high level of TAM receptors was used as positive control and cultured in DMEM.

Crizotinib (PF-023441066) and foretinib (GSK1363089) were purchased from Selleckchem (Souffelweyersheim, France). Recombinant human GAS6 were purchased from R\&D Systems (Lille, France) and reconstituted in PBS. Doxorubicin (D1515) was purchased from Sigma-Aldrich (Saint-Quentin Fallavier, France).

Cell viability/proliferation. Leiomyosarcoma cells were seeded into 96-wells plates at a density of 2000-5000 cells per well. Cells were allowed to adhere overnight before addition of a concentration of crizotinib and foretinib ranging from 0.01 to $10 \mu \mathrm{M}$ or DMSO for additional $72 \mathrm{~h}$. Cell viability was evaluated using CellTiter-Glo Luminescent Cell Viability Assay (Promega, Charbonnières, France). Luminometric measures were performed using the Tecan Infinite 200 PRO microplate reader (Tecan, Lyon, France). Relative cell numbers were normalised to vehicle-treated controls. Results are average of three independent experiments performed in triplicates. Cell proliferation in shRNA clones were assessed by trypan blue exclusion at day 1 and 3 post cell seeding.

Flow cytometry: cell-cycle, apoptosis analysis and protein expression by FACS. In all, $1 \times 10^{6}$ LMS cells were seeded $24 \mathrm{~h}$ before the experiment. Sub-confluent cultures were treated for $48 \mathrm{~h}$ with $5 \mu \mathrm{M}$ of crizotinib, $1 \mu \mathrm{M}$ of foretinib or DMSO. Cells were lifted with trypsin, combined with culture supernatants and collected by centrifugation. For cell cycle analysis, cell pellets were permeabilised in $70 \%$ ethanol overnight at $4{ }^{\circ} \mathrm{C}$ and then stained with propidium iodide $\left(40 \mu \mathrm{g} \mathrm{ml}^{-1}\right)$ and treated with RNAse A $\left(2 \mathrm{mg} \mathrm{ml}^{-1}\right)$ for $1 \mathrm{~h}$ at $37^{\circ} \mathrm{C}$. Apoptosis were analysed using FITC Annexin V apoptosis detection Kit (BD Pharmingen, Paris, France) according to the manufacturer's instructions. Cells were analysed on a flow cytometer (FACScalibur, BD, Le Pont de Claix, France). Results were processed using FlowJo (Tree Star, Inc, Ashland, OR, USA) and CellQuest software (BD Biosciences, Le Pont de Claix, France). Protein detection was performed with both intracellular and extracellular staining. For extracellular staining about $5 \times 10^{5}$ $1 \times 10^{6}$ LMS cells were washed, trypsinised and resuspended in $1 \times$ PBS. A dead cell control was prepared by placing $1 \times 10^{5}$ cells at $56{ }^{\circ} \mathrm{C}$ for $15 \mathrm{~min}$. All cells were first stained with the Live/Dead Fixable Red stain (Invitrogen, Cergy Pontoise, France), which ensure accurate assessment of cell viability in samples after fixation and/or permeabilisation. All cells were then stained with the following goat polyclonal primary antibodies: anti-TYRO3 (AF859); anti-AXL (AF154); anti-Mer (AF891) all from R\&D Systems; or goat IgG isotype control (Novus Biologicals, Cambridge, UK), and a secondary donkey anti-goat IgG Alexa Fluor 488 antibody (Invitrogen). Following the cells were fixed and permeabilised using the eBioscience Fixation \& Permeabilization Kit (eBioscience, Hatfield, UK), as detailed by the supplier's and stained with the same primary and secondary antibodies again. Cells were analysed on a flow cytometer FACScalibur (BD Biosciences). Resultant data were analysed by FlowJo Software (Tree Star, Inc.).

Western blotting. Whole-cell lysates were prepared in RIPA lysis buffer supplemented with protease and phosphatase inhibitors (Bio-Rad factors 1 and 2). Protein concentrations were determined by DC protein assay (Bio-Rad, Marnes-la-Coquette, France) and equal amounts were analysed by SDS-polyacrylamide gel electrophoresis and immunoblotting. Primary antibodies against human 
TYRO3 (\#5585; Cell Signalling, Saint Quentin Yvelines, France), AXL (ABN275; Millipore, Molsheim, France), phosphoAXI (Y779-AF2228; R\&D Systems) and actin (A54441; Sigma-Aldrich) were used, followed by a secondary HRP-linked antibody. Protein bands were detected with Amersham ECL Prime Western Blotting Detection Reagent (GE Healthcare Europe, Velizy-Villacoublay, France) and visualised on autoradiograph film).

Colony formation assay. Anchorage-independent colony formation was performed in agarose. A solution of $1.4 \%$ of agarose mixed 1:1 with $2 \times$ MEM supplemented with FBS to a final concentration of $10 \%$ was layered onto six-well plates. SK-LMS-1 (wild type and shRNA constructions) and IB136 cells were mixed with a similar solution at $0.9 \%$ of agarose and seeded at a density of $1 \times 10^{4}$ cells per well. Medium containing drugs to a final concentration of $5 \mu \mathrm{M}$ of crizotinib, $1 \mu \mathrm{M}$ of foretinib, $5 \mu \mathrm{M}$ doxorubicin, or an equivalent concentration of DMSO was added the following day, in triplicates. Fresh medium containing drugs was renewed every 3 days. Cells were grown for $14-21$ days at $37^{\circ} \mathrm{C}$ in $5 \% \mathrm{CO}_{2}$, and the number of colonies was counted under a microscope. For shRNA experiments, cells were cultured with $2 \mu \mathrm{g}$ of puromycin as plasmid selection drug.

GAS6 ELISA. The LMS cell line lysates were used to coat ELISA plates at $1 \mathrm{mg} \mathrm{ml}^{-1}$ overnight at $4{ }^{\circ} \mathrm{C}$. The following day a specific human GAS6 (R\&D Systems, Abingdon, UK) kit was used following the manufacturer's instructions.

Immunoprecipitation and detection of phosphorylated TYRO3. To evaluate the phosphorylation of TYRO3 by immunoprecipitation, LMS cells were starved for $4 \mathrm{~h}$, then activated with $200 \mathrm{nM}$ of GAS6 for $20 \mathrm{~min}$. Before lysis, cells were treated with a pervanadate solution composed of $10 \mathrm{nM}$ of sodium orthovanadate and $0.15 \%$ of $\mathrm{H}_{2} \mathrm{O}_{2}$ (Schlegel et al, 2013), for $3 \mathrm{~min}$ at $\mathrm{RT}$ to preserve the phosphorylation status of TYRO3. Equal amounts of pervanadatetreated lysates $(500 \mu \mathrm{g})$ were incubated with an anti-phosphotyrosine antibody (PY20 - Invitrogen, Courtaboeuf, France) or mouse IgG2b isotype control (Thermo Fisher Scientific, Villebon sur Yvette, France) for $2 \mathrm{~h}$ at $4{ }^{\circ} \mathrm{C}$ followed by incubation with Protein G-agarose (Millipore) bead slurry pre-coated with BSA 3\% in PBS for $1 \mathrm{~h}$. Immune complexes were collected by centrifugation and washed with PBS with pervanadate. Beads were resuspended in Laemmli buffer (62.5 mm Tri- $\mathrm{HCl}$ (pH 6.8), 25\% glycerol, $5 \% \beta$ mercaptoethanol, $2 \%$ SDS and $0.01 \%$ bromophenol blue) and boiled before analysis by western blotting using a rabbit antiTYRO3 (\#5585; Cell Signalling) or anti AXL (ABN275; Millipore) antibodies. Immunoblots were analysed with Bio-Rad ChemiDoc XRS Imaging System and quantified using Image Lab Software (Bio-Rad).

Production of shRNA clones. Two TYRO3 short hairpins (shRNA), TRCN0000002178 (sh1) and TRCN0000002179 (sh2), two AXL shRNA, TRCN0000000572 (sh3) and TRCN0000000576 (sh4), and a prion protein (shPRPC) were produced into the retroviral vector $\mathrm{pRS}$. The shPRPC vector encodes a shRNA that engages the endogenous RNAi machinery and targets PRPC mRNA; as human cells do not express those proteins, this vector serve as a non-silencing control. Retroviral particles were generated by calcium phosphate transfection of amphotrophic Phoenix packaging cell line with the retroviral vector pRS according to the manufacturer's recommendations (CalPhos Mammalian Transfection Kit_Clontech, Saint-Germain-en-Laye, France). Viral stocks were collected 2 days post transfection, filtered (pore size: $0.45 \mu \mathrm{m})$ and placed in contact with cells for $10-12 \mathrm{~h}$ in the presence of $8 \mu \mathrm{g} \mathrm{ml}^{-1}$ polybrene. Selection was initiated $48 \mathrm{~h}$ post infection with $0.5 \mu \mathrm{g} \mathrm{ml}^{-1}$ of puromycin. Stable clones of SK-LMS1-expressing scramble; TYRO3 or AXL shRNAs selected in the presence of puromycin were subjected to further analysis.
Clinical samples of LMS, synovial sarcoma, dedifferentiated liposarcoma and undifferentiated pleomorphic sarcoma tumours. Two series of sarcoma samples were analysed. Immunohistochemistry for TYRO3, AXL and GAS6 was performed in a series of 107 sarcomas (23 LMS, 24 SS, 22 DDLPS and 38 UPS), from nationally certified tumour bank of Centre Leon Bérard. The TMAs were constructed from representative tumour cores spotted in triplicate along with 5 control samples.

A second series of 251 sarcomas of ATGsarc microarray expression data set (ATGsarc database) from French Sarcoma Groups (FSG) was analysed. The ATGsarc database (http://atgsarc.sarcomabcb.org/) is a web accessible database containing genomic alterations and expression profiles of different sarcoma histological subtypes. This database includes 94 LMS, 94 UPS and 63 DDLPS profiled using Affymetrix U133 Plus 2.0 (Paris, France). Chips that were normalised altogether with GCRMA algorithm. All histologies were centrally reviewed within FSG group of pathologists. The genomic alterations, and differential expression of AXL, TYRO3, MER, GAS6 and Protein S in LMS, and other subtypes were explored. The relapse-free survival of LMS patients with expression levels above or under the mean for all 5 genes was also investigated.

Immunohistochemical analysis and histologic scoring ( $\boldsymbol{H}$-score). To estimate, semiquantitatively, the expression level and intensity of expression of TYRO3, AXL and GAS6, TMAs were stained. Tissue sections of formalin-fixed paraffin-embedded tumour samples were prepared. Immunohistochemistry was performed on the discovery automated platform (Ventana-Roche, BoulogneBillancourt, France) with the following primary antibodies: antiTYRO3 mouse monoclonal (MAB859); anti-AXL goat polyclonal (AF154); and anti-GAS6 goat polyclonal (AF885), all from R\&D Systems. Following the appropriate detection kit: OmniMap antimouse HRP or OmniMap anti-goat HRP were used, both associated to the chromogenic kit ChromoMap DAB, all from Ventana-Roche (Ventana-Roche) as detailed by the supplier. TYRO3, AXL and GAS6 immunoreactivity was analysed semiquantitatively using the $H$-score (Pirker et al, 2012). The percentage of cells at different staining intensities was estimated by visual assessment. The overall (average) staining intensity was scored as 0 (none), 1 (weak), 2 (moderate) or 3 (strong), by visualisation at different magnifications. A minimum of 100 cells was evaluated in calculating the $H$-score.

Statistics. GraphPad Prism (version 5) (Graphpad prism, Paris, France) and IBM SPSS v19 software (IBM, Paris, France) were used to compare samples, conditions and groups of treatment. Survival curves were plotted according to the Kaplan-Meier method and compared using the log rank. Unpaired and paired $P$-values of $P<0.05$ were considered to represent significant difference.

Ethics and study approval by competent authorities. The study was approved by the Ethics committee of the Centre Leon Berard in March 2012. The sarcoma tumour banks and databases received authorisations from the Advisory Committee on Information Processing in Material Research in the Field of Health (CCTIRS) and the French Data Protection Authority (CNIL). The CCTIRS approval obtained on 24 November 2009; CNIL No. 909510 obtained on 5 February 2010. Written informed consent was received from participants before inclusion in the study.

\section{RESULTS}

TYRO3 and AXL are overexpressed in LMS cell lines. The expression of AXL, TYRO3 and MERTK receptors was evaluated in a panel of six LMS cell lines: SK-LMS-1; IB112; IB118; IB133; IB134; and IB136. All cell lines express higher level of phospho 
AXL than normal smooth muscle (Figure 1A). Using immunoprecipitation, phosphorylated TYRO3 was also observed in all cell lines tested (Figure 1B). Fluorescence-activated cell sorting analysis of TYRO3, AXL and MERTK expression confirmed the expression of AXL and TYRO3 proteins, and revealed also MERTK protein expression in LMS cell lines (Figure 1C). GAS6 protein was detected in four out six LMS cell lysates by ELISA (Figure 1D). These results show that all six LMS cell lines express high levels of TAM receptors with phosphorylated forms of AXL and TYRO3.

Inhibition of TYRO3 and AXL in the SK-LMS-1 cell line affects cell viability. To evaluate the role of $A X L$ and TYRO3 genes in LMS growth, the expression of these genes was inhibited using specific shRNA. Exposure to specific shRNA, but not to a control shPRPC, reduced TYRO3 and AXL protein expression as shown on the western blot assay (Figure $2 \mathrm{~A}$ ). In addition, a significant reduction of cell proliferation and colony formation was observed as compared to the control shPRPC, targeting an irrelevant gene (unpaired $t$-test, $P<0.05$; Figure $2 \mathrm{~B}$ and $\mathrm{C}$ ). These results show that both TYRO3 and AXL inhibition reduce cell proliferation of this LMS cell line.

Crizotinib and foretinib inactivate TYRO3. Crizotinib and foretinib are multi-target TKI inhibiting anaplastic lymphoma kinase (ALK), MET (proto-oncogene, receptor tyrosine kinase), as well as AXL and MER, with a lower $\mathrm{IC}_{50}$ reported for foretinib (Graham et al, 2014). To explore whether crizotinib and foretinib affect TYRO3 phosphorylation also, immunoprecipitation experiments were performed using an anti-phospho-protein antibody in cell extracts from LMS exposed to both drugs. The results show a significant decrease of TYRO3 phosphorylation in cell lines treated with the drugs (Figure 3A). Both TKI also decreased AXL phosphorylation in different cell lines. Both tyrosine kinase inhibitors target AXL as expected, but also TYRO3. Quantification of the western blot results is presented in Figure $3 \mathrm{~B}$ and $\mathrm{C}$. Crizotinib and foretinib thus inhibit AXL and TYRO3 activation in cell cultures.

Crizotinib and foretinib inhibit LMS tumour cell line proliferation and affect their morphology. We next assessed the antitumour effect of crizotinib and foretinib on LMS cell lines. Cells were treated with increasing concentrations of these drugs for $72 \mathrm{~h}$. Cell growth was measured using the CellTiter-Glo reagent. The viability curves of crizotinib and foretinib are shown on Figure 3D and E, respectively. Both drugs reduced cell viability as compared to control. SK-LMS-1 and IB134 were the most susceptible cell lines to crizotinib, while IB118 and IB136 were the most sensitive to foretinib. The $\mathrm{IC}_{50}$ values for crizotinib were 8.7, 8.8, 7.5, 3.5, 7.0 and $4.2 \mu \mathrm{M}$ for IB112, IB118, IB133, IB134, IB136 and SK-LMS-1, respectively, and 1.73, 0.78, 1.39, 0.92, 0.79 and $0.84 \mu \mathrm{M}$, respectively, for foretinib consistent with the lowest Kd of foretinib for TAM receptors (Figure 3D and E). The cells more sensitive to the drugs presented a complete deactivation of TYRO3 under both treatments while a partial deactivation of TYRO3 was observed in the less-sensitive cells. There was a significant positive correlation between crizotinib or foretinib sensibility $\left(\mathrm{IC}_{50}\right)$ and rate of TYRO3 phosphorylation after each drug treatment $(r=0.79, P=0.06$, Pearson's $)$ and $(r=0.81$, $P=0.04$, Pearson's), respectively. Both drugs reduced cell density in LMS cells compared to DMSO-treated controls: LMS cells showed an elongated morphology, cytoplasmic shrinking and slender appearance. An increase in cell size was observed for IB112, IB118 and SK-LMS-1 cells (Supplementary Figure 1).

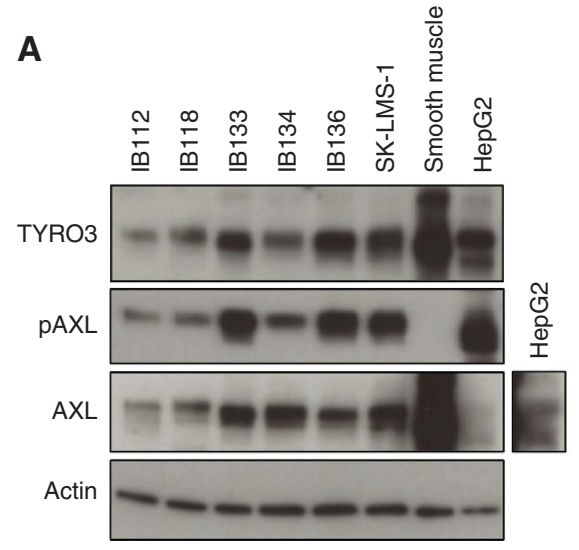

C

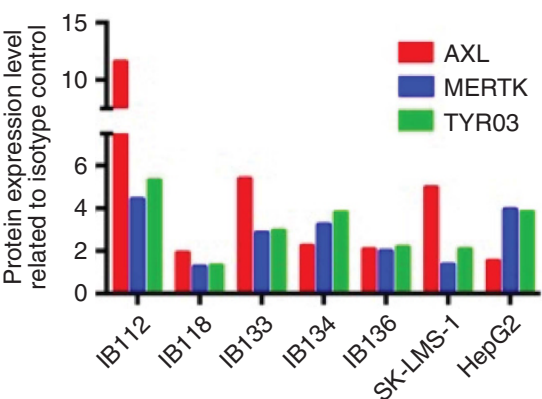

B
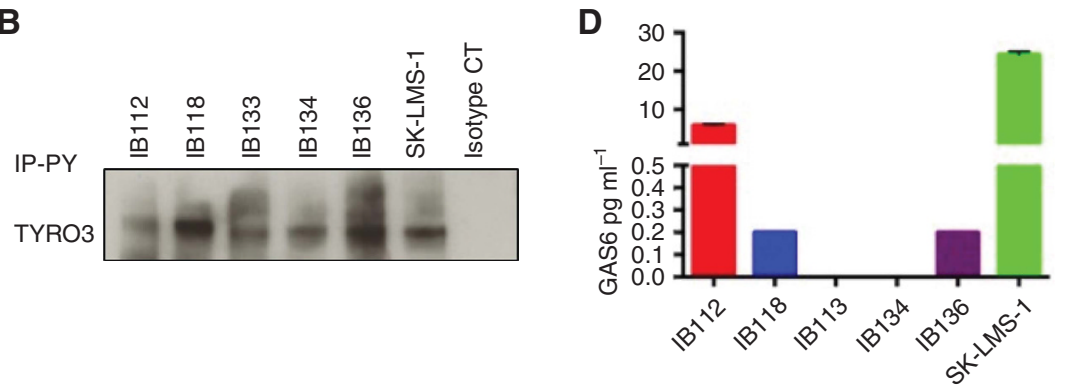

Figure 1. Characterisation of TAM receptor expression in a panel of human LMS cell lines. (A) Lysates from IB112, IB118, IB133, IB134, IB136, SKLMS-1 and HepG2 (positive control) were analysed by western blot. Beta-actin was used as loading control. Longer exposition is shown for HepG2 with AXL antibody. (B) Leiomyosarcoma cells were starved then stimulated with GAS6. After normalisation for protein concentration, phosphotyrosine proteins were immunoprecipitated with a PY20 antibody. The SK-LMS-1 lysate was immunoprecipitated also with an antibody isotype control. Western blot analysis was performed with an anti TYRO3 antibody. (C) Graph showing AXL (red), MER (blue) and TYRO3 (green) expression levels in LMS and HepG2 cells by FACS analysis. Results are shown as fold increase compared to isotype control. (D) Evaluation of GAS6 levels in LMS cells lysates by ELISA. 
A
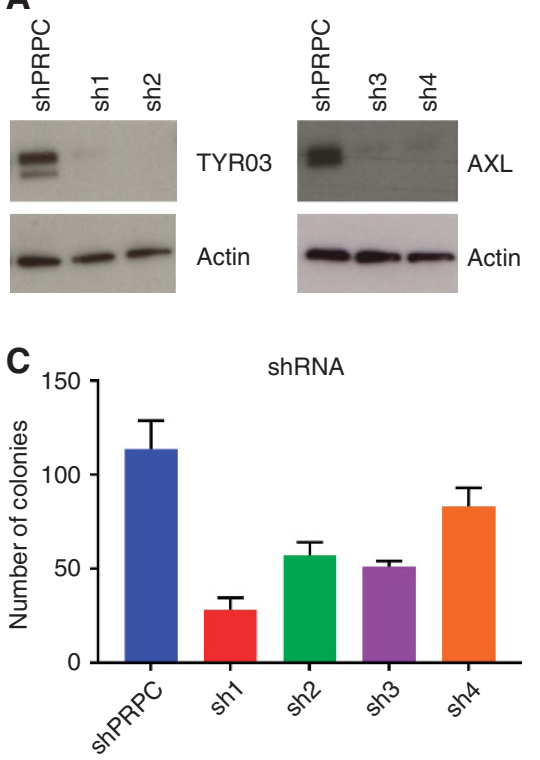

B

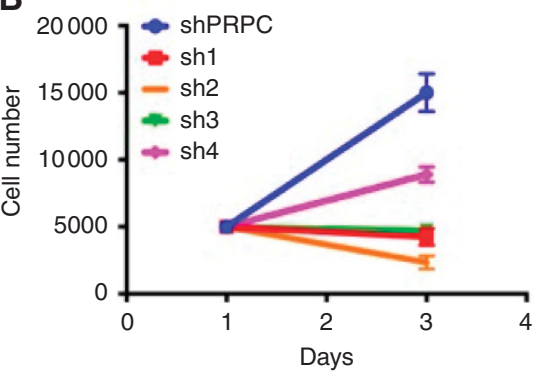

Figure 2. (A) TYRO3 and AXL RTK protein expression following shRNA knockdown. SK-LMS-1 cells comprising TYRO3-targeting shRNA (sh1 and sh2), AXL-targeting shRNA (sh3 and sh4) and control shRNA (shPRPC) show TYRO3 and AXL levels by immunoblotting. (B) Knockdown of TYRO3 and AXL in the SK-LMS-1 cell line affects cell viability. Graph showing the reduction of viability in SK-LMS-1 knocked-down cells cultivated for 3 days. Viable cells were counted using trypan blue. Graphs represent means of two independent experiments performed in duplicates. (C) Graphs showing decrease in colony formation potential for SK-LMS-1 knockdown cells. Graphs represent means of two independent experiments performed in duplicates.

Crizotinib and foretinib induce G2 cell cycle arrest and apoptosis in LMS cells. The impact of crizotinib and foretinib on cell cycle and apoptosis of LMS cell lines was then investigated. Using propidium iodide (PI) staining, crizotinib and foretinib were found to induce a G2/M arrest in the majority of LMS cells tested (Figure 4A). An increase in G2 was observed for IB112, IB133 and IB136, and to a limited extent in SK-LMS-1, while IB134 presented a G1 arrest with an increase in sub-G1 DNA content after exposure to crizotinib and foretinib, respectively (Figure 4A). An augmentation of $>4 n$ DNA content, consistent with the increase in nuclear size, was observed for IB112, IB118 and SK-LMS-1 exposed to crizotinib and foretinib.

Apoptosis in response to crizotinib and foretinib was then investigated. Drugs induced apoptosis in SK-LMS-1, IB134 and IB136 cells lines, as evaluated by annexin V and PI staining, a $>30 \%$ increase in apoptotic cells after exposure to both agents. Apoptosis induction was observed for the three other cells lines to a lower extent (Figure 4B). Morphologically, an increase in cell size and nuclear fragmentation were observed upon treatment with crizotinib and foretinib after DAPI staining. Enlargement of cells and nuclear sizes along with nuclear fragmentation, a hallmark of late apoptosis, was observed for was observed for all cells except IB134 (Figure 4C).

We next tested the effect of those tyrosine kinase inhibitors on anchorage-independent proliferation of LMS cells. IB136 and SKLMS-1, but not the other LMS cell lines tested, were able to grow in an anchorage-independent manner. As shown in Figure 4D, crizotinib inhibited soft-colony formation in a significant manner only for SK-LMS-1 cell line, whereas foretinib efficiently inhibited colony formation in soft agar for both cell lines IB136 and SKLMS-1 $(P<0.05, t$-test $)$. We conclude that TYRO3 and AXL inhibition induce cell death and blocks the proliferation of the LMS cell lines tested.

GAS6 and PROS1 expression is a negative prognostic factor in LMS. To assess the possible role of TYRO3, AXL and their ligand GAS6 in sarcoma patients, their expression was analysed in LMS tumours and other sarcomas subsets. Immunohistochemistry and gene expression analysis were performed in two different data sets of sarcoma patients. Characteristics of LMS patients are presented in Table 1.

TYRO3, AXL and GAS6 expression was investigated in a series of 107 patients with sarcomas, LMS $(n=23)$, DDLPS $(n=22)$, SS $(n=24)$ and UPS $(n=38)$ using IHC. The results, including nuclear staining of TYRO3 are shown on Figure 5A. The percentage of different sarcoma histotypes expressing the proteins is shown (Figure 5B). TYRO3 nuclear staining was observed in 8 out of 21 LMS with detectable TYRO3. The $H$-scoring was significantly higher for TYRO3 and GAS6 in LMS $v s$ other sarcomas (median rank 65.4 vs 50.8 ; $U$-test: $702.5 ; P=0.03$ ) and GAS6 (median rank 66.4 vs 50.6; $U$-test: $688.5 ; P=0.02$ ). AXL $H$ scores did not significantly differ across histotypes (U-test; $P=0.23$ ). GAS6 $H$-score was significantly lower in UPS (median rank 36.4 vs 63.5 ; $U$-test: $633.5 ; P<0.001$ ). Interestingly, the $H$ scores of GAS6 and TYRO3 were highly correlated in the whole data set of sarcoma patients (Pearson's $=0.347, \quad P<0.001$ ) indicating a frequent co-expression of ligand and receptors in the same cells, while no correlations were observed between AXL and GAS6, nor TYRO3 and AXL. Nuclear expression of TYRO3 was observed in $44 \%$ of LMS, and not in any other histotype. The presence of nuclear TYRO3 was significantly associated to coexpression of its ligand GAS6 $(P=0.05)$ suggesting that nuclear locations could be associated with autocrine activation. Neither AXL and GAS6 nor TYRO3 expression correlates to age, site, gender or grade. TYRO3, AXL and GAS6 expression was not correlated with relapse-free survival or overall survival in the cohort of sarcoma patients, nor in the small series of LMS patients.

The second series of patients constitute the ATGsarc database. In all, 251 sarcomas, including $n=94$ LMS, $n=94$ UPS and $n=63$ DDLPS, were used to study TYRO3, AXL, MERTK, GAS6 and PROS1 gene expression. The primary tumours of LMS had a significantly higher expression level of TYRO3 and GAS6 as compared to UPS (Figure 5C and F) but lower levels of MERTK (Figure 5E). Conversely, UPS had higher expression levels of 


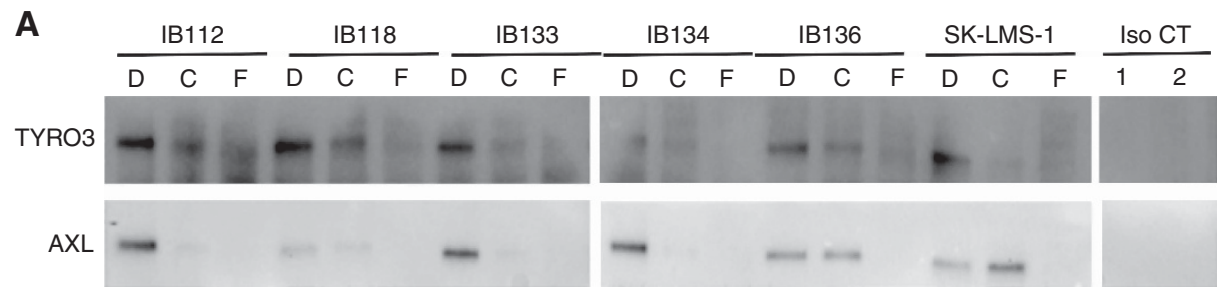

B

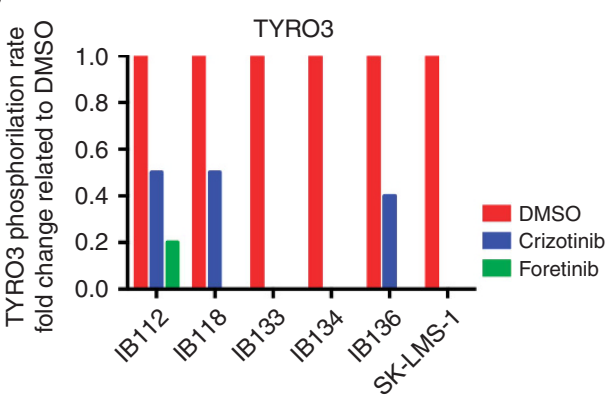

D

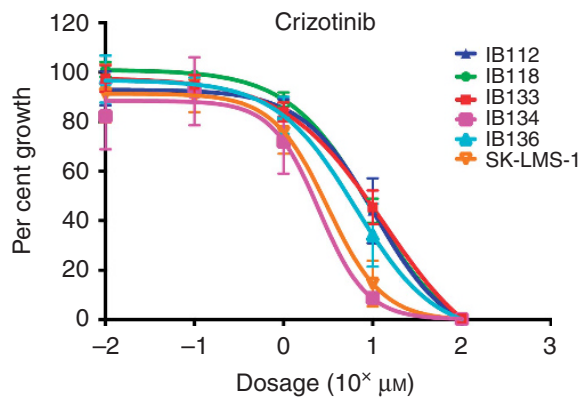

C

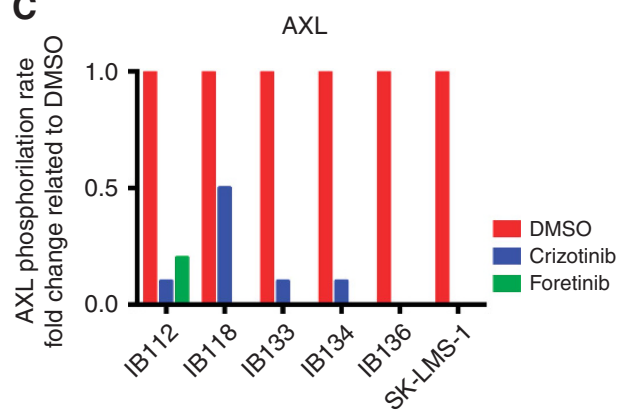

E

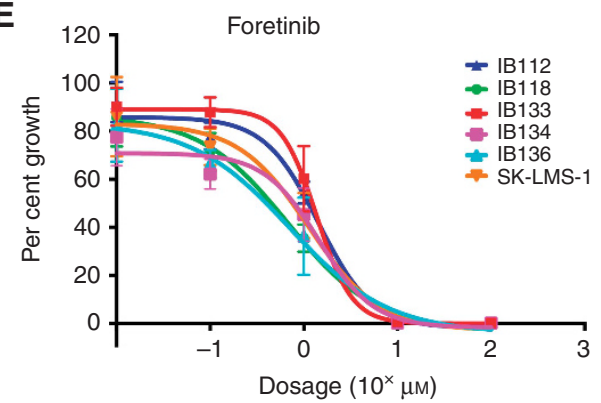

Figure 3. Crizotinib and foretinib deactivate TYRO3 and AXL phosphorylation and lead to decrease in cell viability. (A) Proteins with phosphorylated tyrosines were immunoprecipitated with a PY20 antibody from LMS cell lysates treated with crizotinib and foretinib. IB118 and SKLMS-1 were precipitated also with an isotype control antibody, as shown in the right part of the panel. Western blot analysis was performed with an anti-TYRO3 and -AXL antibodies. Graphs showing TYRO3 (B) or AXL (C) protein quantification of western blot using ChemiDoc Imaging Systems (Bio-Rad). Leiomyosarcoma cells were treated with crizotinib (D) and foretinib (E) at indicated concentrations for $72 \mathrm{~h}$. Viable cells were measured using CellTiterGlo (Promega) and plotted relative to untreated control. Graphs represent means of three independent experiments performed in triplicates. Bars represent s.d.'s.

MERTK (Figure 5E). Protein S expression level was similar in all three histological subgroups (not shown). The PFS of this series (with a median follow-up of 57 months) was then analysed comparing patients with expression levels above and under the mean for all five genes, TYRO3, AXL, MERTK, GAS6 and PROS1. The expression of none of the individual genes was found correlated to PFS, for any of the histotypes, nor for the pooled series. However a trend for a better PFS for low expressors of GAS6 and PROS1 was observed (data not shown). Because GAS6 and PROS1 are both ligands of TYRO3 and AXL, we grouped the patients according to GAS6 and PROS1 expression above or under the mean expression of the series (low/low vs high/low ('mixed'), vs high/high). Interestingly, LMS patients with low expression of both, GAS6 and PROS1 genes, present a significantly better PFS (Figure 5G). These results show that TYRO3, AXL and GAS6 are expressed at higher levels in LMS and expression of its ligands correlates to a worse PFS in LMS patients.

\section{DISCUSSION}

The objective of this work was to investigate the role of TYRO3 and AXL activation in LMS proliferation and survival, and whether these tyrosine kinases receptors could be relevant therapeutic targets in sarcomas. We investigated the expression TYRO3, AXL and GAS6 in LMS cell lines, as well as in series of LMS and other sarcoma tumour tissues, and the impact of inhibitors of TYRO3 and AXL on cell proliferation and survival.

Blocking TYRO3 and AXL with specific shRNA inhibited both the expression of the kinase and cellular proliferation in the SKLMS-1 cell line. TYRO3 and AXL were then targeted using two different multi-tyrosine kinase inhibitors, crizotinib and foretinib. Crizotinib is a multi-kinase inhibitor known to target ALK (Zhu et al, 2009) and the c-Met/hepatocyte growth factor receptor; foretinib is a dual c-MET-VEGFR2 receptor inhibitor that is currently in phase II clinical trials. Both TKI inhibit significantly TYRO3 and AXL (Graham et al, 2014). Indeed, we observed that crizotinib and foretinib blocked TYRO3 and AXL tyrosine kinase receptor phosphorylation. Both crizotinib and foretinib diminish or completely abolish TYRO3 as well AXL phosphorylation in LMS cell lines. Phosphorylation of TYRO3 was entirely abolished by crizotinib or foretinib in the most sensitive LMS cells. A strong positive correlation was established between levels of TYRO3 phosphorylation under crizotinib and foretinib treatment and drug sensibility in LMS cell lines.

Exposure to both kinase inhibitors induced cell cycle arrest and/ or apoptosis in the LMS cell lines tested, along with modifications 

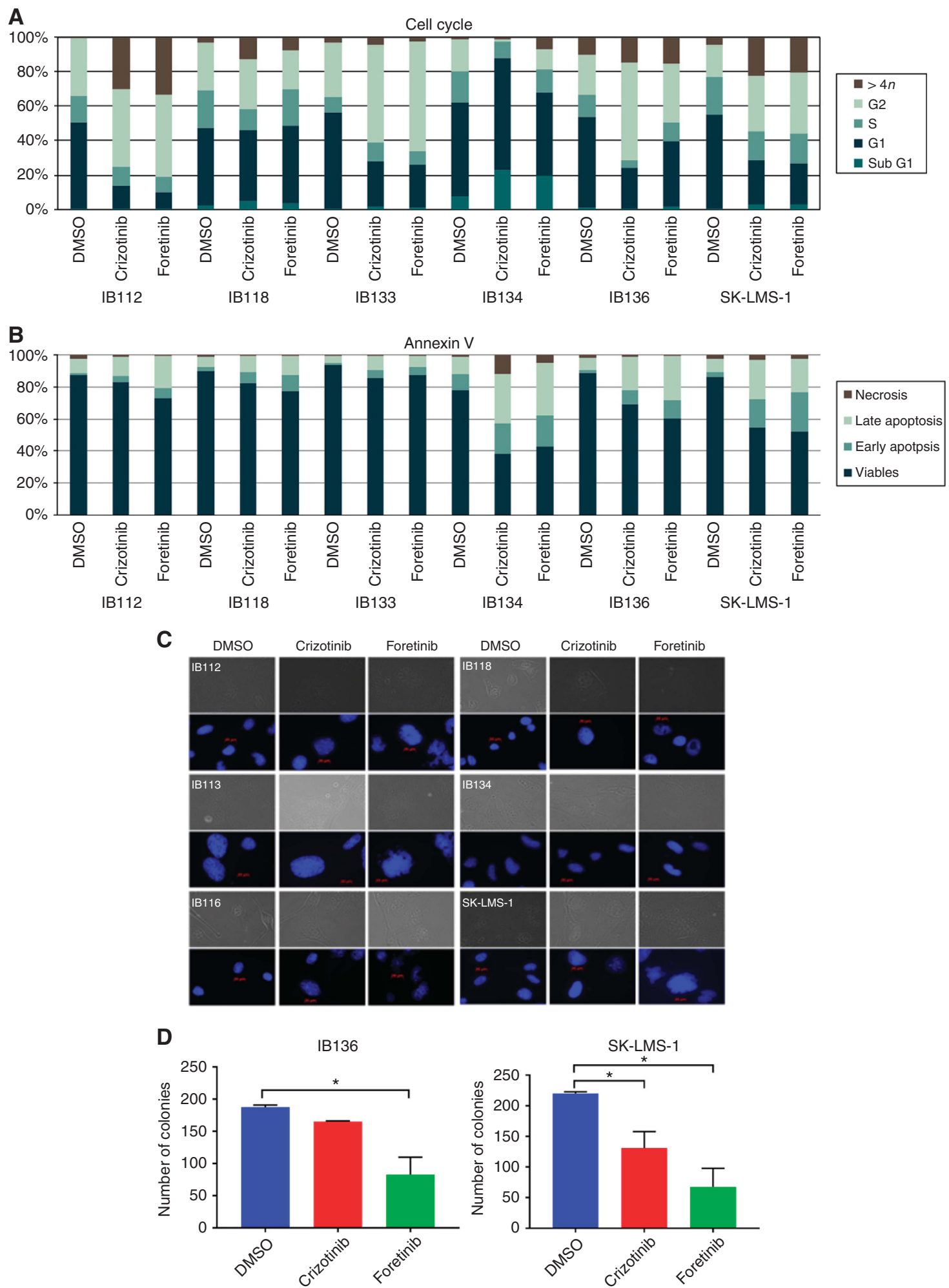

Figure 4. Drugs increase cell and nuclear size, affect cell cycle and induce apoptosis. (A) Crizotinib (5 $\mu \mathrm{M})$ and foretinib (1 $\mu \mathrm{m})$ induced G2-M cell cycle arrest and/or $>4 n$ increase in LMS cells after $48 \mathrm{~h}$ of treatment. The proportion of cells in each cell cycle phase is graphed as percentage of the total. Results are mean of three independent experiments. (B) Annexin $\mathrm{V}$ and propidium iodide (PI) measured by flow cytometry. The proportion of viable or dead cells in each apoptosis phase is graphed as percentage of total. Results are mean of three independent experiments. (C) Phase contrast and fluorescence microscopy of DAPI-stained cells receiving vehicle, crizotinib or foretinib for $72 \mathrm{~h}$. (D) Crizotinib and foretinib reduces colony size in anchorage-independent growth of LMS cells. SK-LMS-1 and IB136 were grown in soft agar for 14 days, treated with $5 \mu \mathrm{g}$ of crizotinib, $1 \mu \mathrm{g}$ of foretinib or DMSO for 6 days then analysed by microscopy. This picture is representative of two experiments, performed in triplicates. ${ }^{\star} P<0.01$. 
Table 1. Description of the ATG and CLB series of LMS patients

\begin{tabular}{|c|c|c|}
\hline & ATGsarc series & CLB IHC series \\
\hline Clinical features & $N(\%)$ & $N(\%)$ \\
\hline $\begin{array}{l}\text { Gender } \\
\text { Female } \\
\text { Male }\end{array}$ & $\begin{array}{l}129(51) \\
122(49)\end{array}$ & $\begin{array}{l}55(51) \\
52(49)\end{array}$ \\
\hline Median age & 63 & 61 \\
\hline Range & $15-92$ & $13-86$ \\
\hline $\begin{array}{l}\text { Histopatologic grade } \\
1 \\
2 \\
3 \\
\text { Unknown }\end{array}$ & $\begin{array}{c}14(6) \\
78(31) \\
137(55) \\
22(9)\end{array}$ & $\begin{array}{c}10(9) \\
35(33) \\
56(52) \\
6(6)\end{array}$ \\
\hline $\begin{array}{l}\text { Histologies } \\
\text { LMS } \\
\text { UPS } \\
\text { DDLPS } \\
\text { Synovial sarcoma }\end{array}$ & $\begin{array}{l}94(37) \\
94(37) \\
63(26) \\
0\end{array}$ & $\begin{array}{l}23(21) \\
38(37) \\
22(21) \\
24(22)\end{array}$ \\
\hline $\begin{array}{l}\text { Primary tumour site at } \\
\text { diagnosis } \\
\text { Chest wall } \\
\text { Lower extremity } \\
\text { Upper extremity } \\
\text { Uterus } \\
\text { Retroperitoneal } \\
\text { Other }\end{array}$ & $\begin{aligned} 39 & (16) \\
106 & (42) \\
34 & (14) \\
1 & (0.5) \\
64 & (25) \\
7 & (3)\end{aligned}$ & $\begin{array}{c}10(9) \\
37(35) \\
19(18) \\
1(1) \\
25(23) \\
14(13)\end{array}$ \\
\hline $\begin{array}{l}\text { Size (mm) } \\
\quad<50 \text { (non-bulky) } \\
>50 \text { (bulky) } \\
\text { Unknown }\end{array}$ & $\begin{array}{r}17(7) \\
207(82) \\
27(11)\end{array}$ & $\begin{array}{c}23(21) \\
79(73) \\
5(5)\end{array}$ \\
\hline $\begin{array}{l}\text { Metastatic at diagnosis } \\
\text { Yes } \\
\text { No }\end{array}$ & $\begin{array}{c}13(5) \\
238(95)\end{array}$ & $\begin{array}{c}3(3) \\
104(97)\end{array}$ \\
\hline
\end{tabular}

in cell and nucleus morphology and size. Even though both crizotinib and foretinib are multi-target TKI, these observations are consistent with shRNA results and show a concomitant inhibition of phosphorylation of the two receptors with an impact on cell proliferation and survival, strongly suggesting a contribution of TYRO3 and AXL in LMS cell proliferation.

The relevance of these observations was then investigated in tumour samples. TYRO3, AXL and GAS6 were investigated at protein level, in LMS tumours using IHC. TYRO3 and GAS6 were expressed at higher level in LMS $v s$ other sarcomas. Interestingly, a strong correlation between TYRO3 and GAS6 expression was observed. The lack of correlation of TYRO3, AXL and GAS6 expression on IHC, and PFS and OS is likely related to the small size of the series, the lack of documentation of PROS1 expression, the redundancy of TAM receptors function of and the difficulty to elaborate combined criteria as for mRNA expression. TYRO3, AXL, MERTK, GAS6 and PROS1 mRNA expression was measured in different sarcoma histotypes: LMS; UPS; and DDLPS. Leiomyosarcoma express significant higher level of TYRO3 and GAS6 then other sarcomas. None of the individual TAM receptors, AXL, TYRO3 or MER, had individual prognostic value for PFS or OS possibly because of the redundancy of these receptors in the presence of the ligands, but also probably because of the small size of the series. This former hypothesis is supported by the observation that a combined parameter of GAS6 and PROS1 low expression was associated with a better PFS. Leiomyosarcoma patients expressing higher levels of GAS6 and/or PROS1 are more prone to relapse and/or develop metastasis in this series of patients. Taken together, these results strongly suggest that TYRO3 and its ligands have an important role in LMS biology and deserve to be explored as a potential therapeutic target in clinical setting.

Expression of TAM receptor was already reported in sarcomas. Most of the data are related to AXL. Beyond our study on LMS (el Sayadi et al, 2013), AXL expression was reported in uterine LMS (Lusby et al, 2013) and in DDLPS, (Peng et al, 2011) and Ewing sarcoma, where AXL expression is correlated with a worse overall survival (Fleuren et al, 2014). AXL expression is also correlated to a poor outcome in MLPS patients (Hoffman et al, 2013). AXL and its ligand GAS6 were found expressed in Kaposi sarcoma in both KS cell lines and tumours. MER and TYRO3 were not found expressed in KS tumours. AXL blockade by MAb173, a specific anti-AXL antibody diminished cell growth, in vitro and in vivo as well as invasion (Liu et al, 2010). In osteosarcoma, AXL is associated with cell motility and invasiveness (Nakano et al, 2003), and phosphoAXL expression was recently found correlated with a worse prognosis (Han et al, 2013).

The expression of TYRO3 had conversely not been reported in sarcomas besides our previous report on 2 LMS cell lines and 13 tumour samples (el Sayadi et al, 2013). The results presented here show that this receptor is specifically overexpressed in LMS, and its inhibition is associated with reduced cell viability, increased apoptosis, cell cycle blockade and reduced colony formation. Both receptors and ligands are expressed by sarcoma cells: this autocrine situation is associated with a significantly increased risk of relapse in LMS patients.

It was intriguing to observe that nuclear expression of TYRO3 was observed specifically in LMS, and mostly in tumours coexpressing GAS6 and TYRO3 (not shown). Nuclear expression of tyrosine kinase has been recently reported in different sarcoma types, including KIT in GIST, IGF1R in a variety of sarcoma histotypes; the significance of this location is unclear but correlated with receptor activation and response to targeted agents in these models (Tabone-Eglinger et al, 2008; Asmane et al, 2012). The notion that cell surface receptors can migrate to the nucleus and act as transcription factors has been reported since 1990. Epidermal growth factor (EGF), growth hormone, insulin receptor, fibroblast growth factor receptors and transforming growth factor beta are among the first receptors observed in the nucleus (Podlecki et al, 1987; Kamio et al, 1990; Lobie et al, 1991; Maher, 1996; Zwaagstra et al, 2000). Nuclear detection of EGF receptor (EGFR) has been identified in a variety of cancer cells and primary tumours (Gusterson et al, 1985), mainly in highly proliferative tissues EGFR function as a transcription factor activating genes required for highly proliferating activities such as cyclin D1 (Lin et al, 2001). High expression of nuclear EGFR is correlated to a worst overall survival in breast cancer patients (Lo et al, 2005). Epidermal growth factor receptor nuclear expression is also correlated to a worst disease-free survival rate in head and neck squamous cell cancer (Psyrri et al, 2005).

For TAM receptors, there are few reports of nuclear localisation of AXL and MER. Prolonged GAS6 exposition leads to the production of a partially $N$-glycosylated form of MER that localises preferentially in the nucleus of ALL cells (Migdall-Wilson et al, 2012). Further, AXL and p-AXL have been detected widespread in the nucleus of schwannoma cells (Ammoun et al, 2014). The present work is the first report of the presence of TYRO3 in the nucleus of tumour cells. The mechanism and significance of the specificity of nuclear localisation in LMS remains to be understood. The identification of the contribution of TYRO3 and GAS6 in LMS cell lines and fresh tumours points to the possible vascular smooth muscle cell origin of subsets of LMS cells in humans. TYRO3, AXL and GAS6 are indeed important signalling molecules for vascular smooth muscle cells (Melaragno et al, 2004).

In conclusion, this work shows that TYRO3 and AXL and their ligands are involved in the growth of LMS cell lines, are present and activated in tumour samples and that their expression 

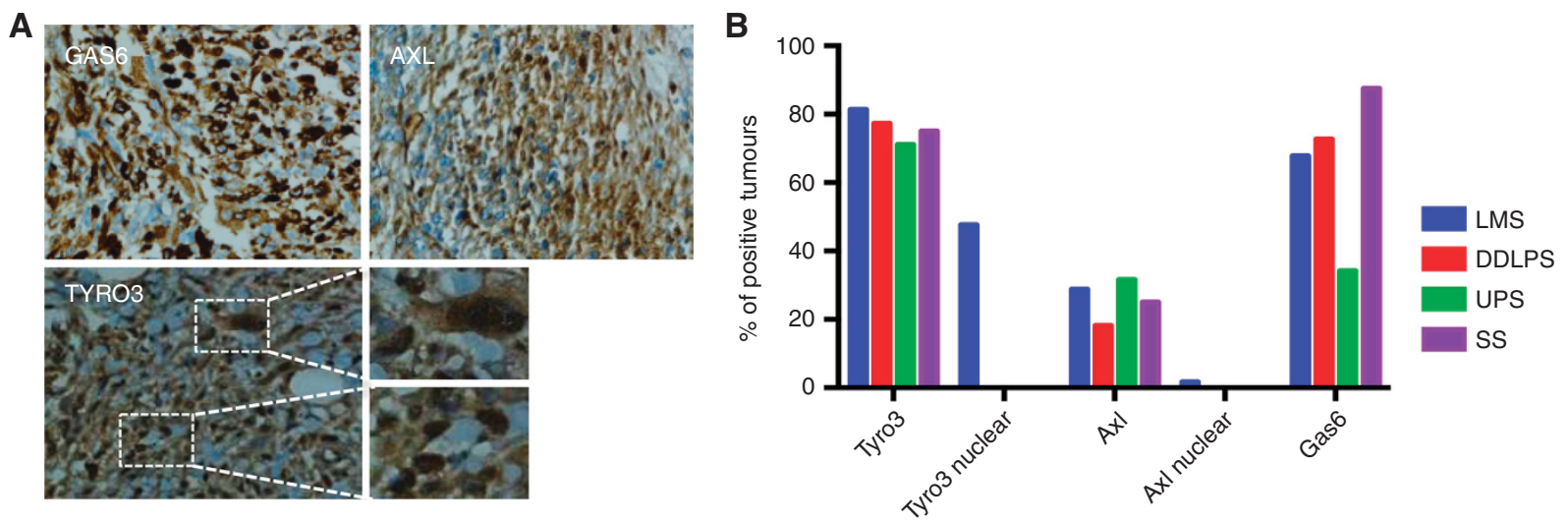

C

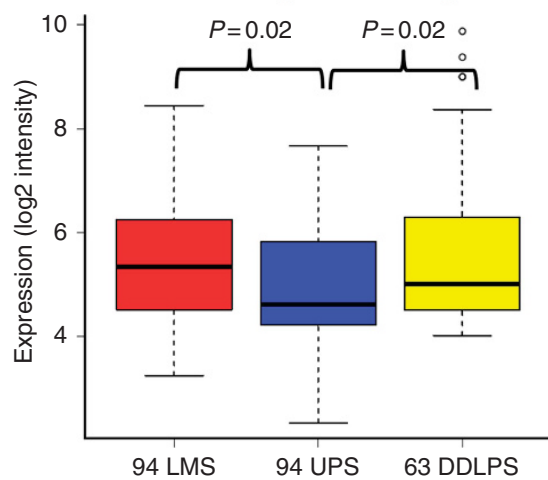

$\mathbf{F}$

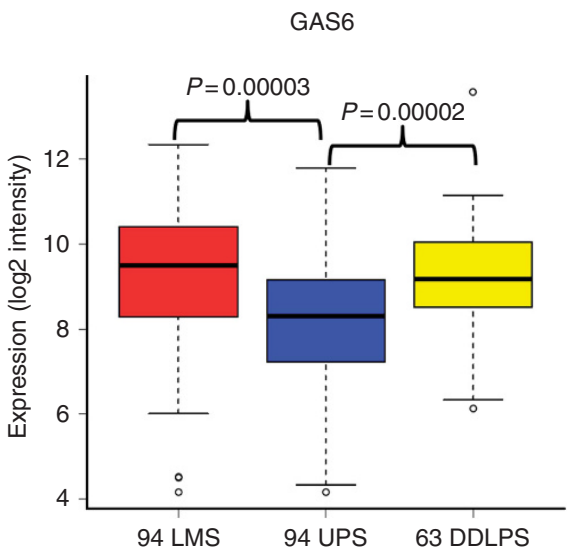

D

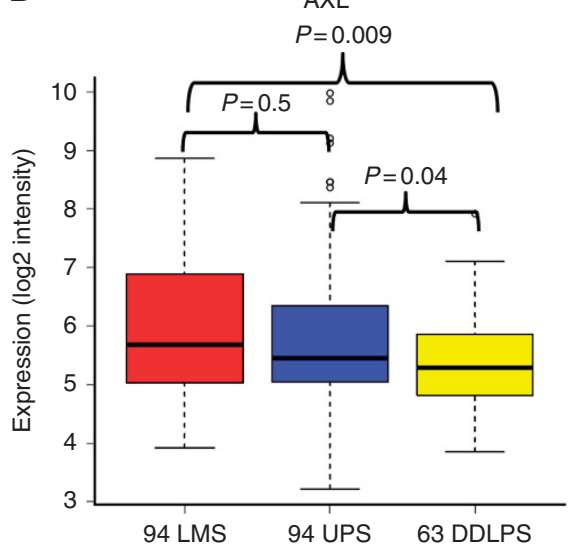

G

G GAS6 (202177_at) and PROS1 (207808_s_at)

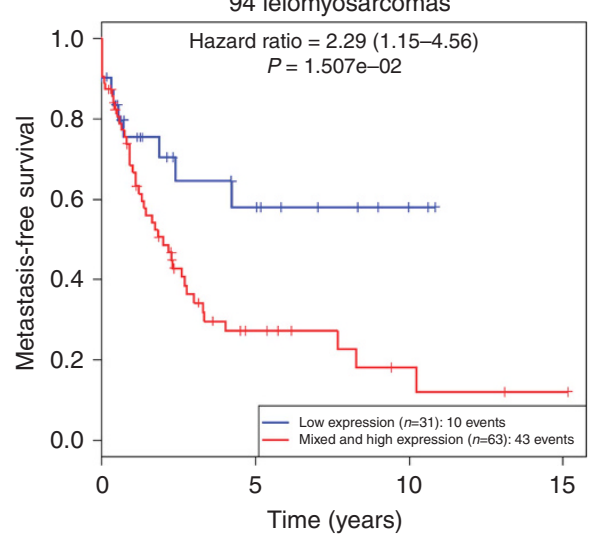

E

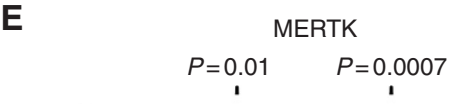

Figure 5. TYRO3, AXL and GAS6 expression in sarcomas. (A) Representative example of immunohistochemistry on LMS tissues with anti-AXL, antiTYRO3 and anti-GAS6 antibodies. TYRO3 nuclear expression is shown in detail. Original magnification $\times 20$ and $\times 40$. (B) Graph showing the percentage of positive samples from each sarcoma hystotype analysed. Cytoplasmic or nuclear staining was plotted separately. (C-F) Gene expression analysis of TYRO3, AXL, GAS6 and PROS1 transcripts, respectively. Data are from gene expression and outcome in 251 sarcoma patients' samples from ATGsarc microarray database. (G) Kaplan-Meier curve for progression-free survival of 94 LMS patients with low or mixed and high expression levels of GAS6 and PROS1 genes cluster. P-values in log-rank test are indicated. $n=$ number of patients in each group. Median PFS are expressed in years.

correlates with a poor outcome in sarcoma patients. Targeting those proteins with specific TKI may represent a new potential treatment for LMS that deserves further investigation.

\section{ACKNOWLEDGEMENTS}

We thank Christophe Caux for valuable contribution. We are thankful to Rodrigo Nalio and Isabelle Durand for flow cytometry support. This work was supported by the National Cancer
Institute: LYric (DGOS-INCA 4664), NetSARC INTERSARC, RREPS, Agence Nationale de la Recherche: LabEx DEvweCAN, (ANR-10-LABX-0061), Eurosarc (FP7-278742), La Ligue contre le Cancer de L'Ardeche and Association pour la recherche sur le cancer.

\section{CONFLICT OF INTEREST}

The authors declare no conflict of interest. 


\section{REFERENCES}

Ammoun S, Provenzano L, Zhou L, Barczyk M, Evans K, Hilton DA, Hafizi S, Hanemann CO (2014) Axl/Gas6/NFkappaB signalling in schwannoma pathological proliferation, adhesion and survival. Oncogene 33(3): 336-346.

Asmane I, Watkin E, Alberti L, Duc A, Marec-Berard P, Ray-Coquard I, Cassier P, Decouvelaere AV, Ranchere D, Kurtz JE, Bergerat JP, Blay JY (2012) Insulin-like growth factor type 1 receptor (IGF-1R) exclusive nuclear staining: a predictive biomarker for IGF-1R monoclonal antibody (Ab) therapy in sarcomas. Eur J Cancer 48(16): 3027-3035.

Avilla E, Guarino V, Visciano C, Liotti F, Svelto M, Krishnamoorthy G, Franco R, Melillo RM (2011) Activation of TYRO3/AXL tyrosine kinase receptors in thyroid cancer. Cancer Res 71(5): 1792-1804.

Benson C, Ray-Coquard I, Sleijfer S, Litiere S, Blay JY, Le Cesne A, Papai Z, Judson I, Schoffski P, Chawla S, Gil T, Piperno-Neumann S, Marreaud S, Dewji MR, van der Graaf WT (2016) Outcome of uterine sarcoma patients treated with pazopanib: a retrospective analysis based on two European Organisation for Research and Treatment of Cancer (EORTC) Soft Tissue and Bone Sarcoma Group (STBSG) clinical trials 62043 and 62072. Gynecol Oncol 142(1): 89-94.

Brewer P, Sumathi V, Grimer RJ, Carter SR, Tillman RM, Abudu A, Jeys L (2012) Primary leiomyosarcoma of bone: analysis of prognosis. Sarcoma 2012: 636849 .

Chibon F, Lagarde P, Salas S, Perot G, Brouste V, Tirode F, Lucchesi C, de Reynies A, Kauffmann A, Bui B, Terrier P, Bonvalot S, Le Cesne A, Vince-Ranchere D, Blay JY, Collin F, Guillou L, Leroux A, Coindre JM, Aurias A (2010) Validated prediction of clinical outcome in sarcomas and multiple types of cancer on the basis of a gene expression signature related to genome complexity. Nat Med 16(7): 781-787.

Clark MA, Fisher C, Judson I, Thomas JM (2005) Soft-tissue sarcomas in adults. $N$ Engl J Med 353(7): 701-711.

Ducimetiere F, Lurkin A, Ranchere-Vince D, Decouvelaere AV, Isaac S, Claret-Tournier C, Suignard Y, Salameire D, Cellier D, Alberti L, Bringuier PP, Blay JY, Ray-Coquard I (2010) Incidence rate, epidemiology of sarcoma and molecular biology. Preliminary results from EMS study in the Rhone-Alpes region. Bull Cancer 97(6): 629-641.

el Sayadi H, Pissaloux D, Alberti L, Tabone-Eglinger S, Ranchere D, Decouvelaere AV, Tabone E, Ray-Coquard I, Caux C, Fayette J, Blay JY (2013) Autocrine role for Gas6 with Tyro3 and Axl in leiomyosarcomas. Target Oncol 8(4): 261-269.

Fleuren ED, Hillebrandt-Roeffen MH, Flucke UE, Te Loo DM, Boerman OC, van der Graaf WT, Versleijen-Jonkers YM (2014) The role of AXL and the in vitro activity of the receptor tyrosine kinase inhibitor BGB324 in Ewing sarcoma. Oncotarget 5(24): 12753-12768.

Graham DK, DeRyckere D, Davies KD, Earp HS (2014) The TAM family: phosphatidylserine sensing receptor tyrosine kinases gone awry in cancer. Nat Rev Cancer 14(12): 769-785.

Grellety T, Laroche-Clary A, Chaire V, Lagarde P, Chibon F, Neuville A, Italiano A (2015) PRIMA-1(MET) induces death in soft-tissue sarcomas cell independent of p53. BMC Cancer 15: 684.

Gusterson B, Cowley G, McIlhinney J, Ozanne B, Fisher C, Reeves B (1985) Evidence for increased epidermal growth factor receptors in human sarcomas. Int J Cancer 36(6): 689-693.

Hafizi S, Dahlback B (2006) Gas6 and protein S. Vitamin K-dependent ligands for the Axl receptor tyrosine kinase subfamily. FEBS J 273(23): 5231-5244.

Han J, Tian R, Yong B, Luo C, Tan P, Shen J, Peng T (2013) Gas6/Axl mediates tumor cell apoptosis, migration and invasion and predicts the clinical outcome of osteosarcoma patients. Biochem Biophys Res Commun 435(3): 493-500.

Hoffman A, Ghadimi MP, Demicco EG, Creighton CJ, Torres K, Colombo C, Peng T, Lusby K, Ingram D, Hornick JL, Wang WL, Ravi V, Lazar AJ, Lev D, Pollock RE (2013) Localized and metastatic myxoid/round cell liposarcoma: clinical and molecular observations. Cancer 119(10): $1868-1877$.

Kamio T, Shigematsu K, Sou H, Kawai K, Tsuchiyama H (1990) Immunohistochemical expression of epidermal growth factor receptors in human adrenocortical carcinoma. Hum Pathol 21(3): 277-282.

Lai C, Lemke G (1991) An extended family of protein-tyrosine kinase genes differentially expressed in the vertebrate nervous system. Neuron 6(5): 691-704.
Le Cesne A, Blay JY, Judson I, Van Oosterom A, Verweij J, Radford J, Lorigan P, Rodenhuis S, Ray-Coquard I, Bonvalot S, Collin F, Jimeno J, Di Paola E, Van Glabbeke M, Nielsen OS (2005) Phase II study of ET-743 in advanced soft tissue sarcomas: a European Organisation for the Research and Treatment of Cancer (EORTC) soft tissue and bone sarcoma group trial. J Clin Oncol 23(3): 576-584.

Lee-Sherick AB, Eisenman KM, Sather S, McGranahan A, Armistead PM, McGary CS, Hunsucker SA, Schlegel J, Martinson H, Cannon C, Keating AK, Earp HS, Liang X, DeRyckere D, Graham DK (2013) Aberrant Mer receptor tyrosine kinase expression contributes to leukemogenesis in acute myeloid leukemia. Oncogene 32(46): 5359-5368.

Lemke G, Rothlin CV (2008) Immunobiology of the TAM receptors. Nat Rev Immunol 8(5): 327-336.

Lin SY, Makino K, Xia W, Matin A, Wen Y, Kwong KY, Bourguignon L, Hung MC (2001) Nuclear localization of EGF receptor and its potential new role as a transcription factor. Nat Cell Biol 3(9): 802-808.

Linger RM, Keating AK, Earp HS, Graham DK (2010) Taking aim at Mer and Axl receptor tyrosine kinases as novel therapeutic targets in solid tumors. Expert Opin Ther Targets 14(10): 1073-1090.

Liu R, Gong M, Li X, Zhou Y, Gao W, Tulpule A, Chaudhary PM, Jung J, Gill PS (2010) Induction, regulation, and biologic function of Axl receptor tyrosine kinase in Kaposi sarcoma. Blood 116(2): 297-305.

Lo HW, Xia W, Wei Y, Ali-Seyed M, Huang SF, Hung MC (2005) Novel prognostic value of nuclear epidermal growth factor receptor in breast cancer. Cancer Res 65(1): 338-348.

Lobie PE, Barnard R, Waters MJ (1991) The nuclear growth hormone receptor binding protein. Antigenic and physicochemical characterization. J Biol Chem 266(33): 22645-22652.

Lusby K, Savannah KB, Demicco EG, Zhang Y, Ghadimi MP, Young ED, Colombo C, Lam R, Dogan TE, Hornick JL, Lazar AJ, Hunt KK, Anderson ML, Creighton CJ, Lev D, Pollock RE (2013) Uterine leiomyosarcoma management, outcome, and associated molecular biomarkers: a single institution's experience. Ann Surg Oncol 20(7): 2364-2372.

Maher PA (1996) Nuclear Translocation of fibroblast growth factor (FGF) receptors in response to FGF-2. J Cell Biol 134(2): 529-536.

Melaragno MG, Cavet ME, Yan C, Tai LK, Jin ZG, Haendeler J, Berk BC (2004) Gas6 inhibits apoptosis in vascular smooth muscle: role of Axl kinase and Akt. J Mol Cell Cardiol 37(4): 881-887.

Miettinen M (2014) Smooth muscle tumors of soft tissue and non-uterine viscera: biology and prognosis. Mod Pathol 27(Suppl 1): S17-S29.

Migdall-Wilson J, Bates C, Schlegel J, Brandao L, Linger RM, DeRyckere D, Graham DK (2012) Prolonged exposure to a Mer ligand in leukemia: Gas6 favors expression of a partial Mer glycoform and reveals a novel role for Mer in the nucleus. PLoS One 7(2): e31635.

Mir O, Brodowicz T, Italiano A, Wallet J, Blay JY, Bertucci F, Chevreau C, Piperno-Neumann S, Bompas E, Salas S, Perrin C, Delcambre C, Liegl-Atzwanger B, Toulmonde M, Dumont S, Ray-Coquard I, Clisant S, Taieb S, Guillemet C, Rios M, Collard O, Bozec L, Cupissol D, Saada-Bouzid E, Lemaignan C, Eisterer W, Isambert N, Chaigneau L, Cesne AL, Penel N (2016) Safety and efficacy of regorafenib in patients with advanced soft tissue sarcoma (REGOSARC): a randomised, doubleblind, placebo-controlled, phase 2 trial. Lancet Oncol 17(12): 1732-1742.

Nakano T, Tani M, Ishibashi Y, Kimura K, Park YB, Imaizumi N, Tsuda H, Aoyagi K, Sasaki H, Ohwada S, Yokota J (2003) Biological properties and gene expression associated with metastatic potential of human osteosarcoma. Clin Exp Metastasis 20(7): 665-674.

Peng T, Zhang P, Liu J, Nguyen T, Bolshakov S, Belousov R, Young ED, Wang X, Brewer K, Lopez-Terrada DH, Oliveira AM, Lazar AJ, Lev D (2011) An experimental model for the study of well-differentiated and dedifferentiated liposarcoma; deregulation of targetable tyrosine kinase receptors. Lab Invest 91(3): 392-403.

Pirker R, Pereira JR, von Pawel J, Krzakowski M, Ramlau R, Park K, de Marinis F, Eberhardt WE, Paz-Ares L, Storkel S, Schumacher KM, von Heydebreck A, Celik I, O’Byrne KJ (2012) EGFR expression as a predictor of survival for first-line chemotherapy plus cetuximab in patients with advanced non-small-cell lung cancer: analysis of data from the phase 3 FLEX study. Lancet Oncol 13(1): 33-42.

Podlecki DA, Smith RM, Kao M, Tsai P, Huecksteadt T, Brandenburg D, Lasher RS, Jarett L, Olefsky JM (1987) Nuclear translocation of the insulin receptor. A possible mediator of insulin's long term effects. J Biol Chem 262(7): 3362-3368.

Psyrri A, Yu Z, Weinberger PM, Sasaki C, Haffty B, Camp R, Rimm D, Burtness BA (2005) Quantitative determination of nuclear and 
cytoplasmic epidermal growth factor receptor expression in oropharyngeal squamous cell cancer by using automated quantitative analysis. Clin Cancer Res 11(16): 5856-5862.

Ratan R, Patel SR (2016) Chemotherapy for soft tissue sarcoma. Cancer 122(19): 2952-2960.

Schlegel J, Sambade MJ, Sather S, Moschos SJ, Tan AC, Winges A, DeRyckere D, Carson CC, Trembath DG, Tentler JJ, Eckhardt SG, Kuan PF, Hamilton RL, Duncan LM, Miller CR, Nikolaishvili-Feinberg N, Midkiff BR, Liu J, Zhang W, Yang C, Wang X, Frye SV, Earp HS, Shields JM, Graham DK (2013) MERTK receptor tyrosine kinase is a therapeutic target in melanoma. J Clin Invest 123(5): 2257-2267.

Schoffski P, Chawla S, Maki RG, Italiano A, Gelderblom H, Choy E, Grignani G, Camargo V, Bauer S, Rha SY, Blay JY, Hohenberger P, D’Adamo D, Guo M, Chmielowski B, Le Cesne A, Demetri GD, Patel SR (2016) Eribulin versus dacarbazine in previously treated patients with advanced liposarcoma or leiomyosarcoma: a randomised, open-label, multicentre, phase 3 trial. Lancet 387(10028): 1629-1637.

Suarez RM, Chevot F, Cavagnino A, Saettel N, Radvanyi F, Piguel S, Bernard-Pierrot I, Stoven V, Legraverend M (2013) Inhibitors of the TAM subfamily of tyrosine kinases: synthesis and biological evaluation. Eur J Med Chem 61: 2-25.

Tabone-Eglinger S, Subra F, El Sayadi H, Alberti L, Tabone E, Michot JP, Theou-Anton N, Lemoine A, Blay JY, Emile JF (2008) KIT mutations induce intracellular retention and activation of an immature form of the KIT protein in gastrointestinal stromal tumors. Clin Cancer Res 14(8): 2285-2294.

Toro JR, Travis LB, Wu HJ, Zhu K, Fletcher CD, Devesa SS (2006) Incidence patterns of soft tissue sarcomas, regardless of primary site, in the surveillance, epidemiology and end results program, 1978-2001: An analysis of 26,758 cases. Int J Cancer 119(12): 2922-2930.

Trent JC, Lazar AJ, Zhang W (2007) Molecular approaches to resolve diagnostic dilemmas: the case of gastrointestinal stromal tumor and leiomyosarcoma. Future Oncol 3(6): 629-637.
Vajkoczy P, Knyazev P, Kunkel A, Capelle HH, Behrndt S, von Tengg-Kobligk H, Kiessling F, Eichelsbacher U, Essig M, Read TA, Erber R, Ullrich A (2006) Dominant-negative inhibition of the Axl receptor tyrosine kinase suppresses brain tumor cell growth and invasion and prolongs survival. Proc Natl Acad Sci USA 103(15): 5799-5804.

van der Graaf WT, Blay JY, Chawla SP, Kim DW, Bui-Nguyen B, Casali PG, Schoffski P, Aglietta M, Staddon AP, Beppu Y, Le Cesne A, Gelderblom H, Judson IR, Araki N, Ouali M, Marreaud S, Hodge R, Dewji MR, Coens C, Demetri GD, Fletcher CD, Dei Tos AP, Hohenberger P, Tissue ES. Bone Sarcoma G, Group Ps (2012) Pazopanib for metastatic soft-tissue sarcoma (PALETTE): a randomised, double-blind, placebo-controlled phase 3 trial. Lancet 379(9829): 1879-1886.

Yeh CY, Shin SM, Yeh HH, Wu TJ, Shin JW, Chang TY, Raghavaraju G, Lee CT, Chiang JH, Tseng VS, Lee YC, Shen CH, Chow NH, Liu HS (2011) Transcriptional activation of the Axl and PDGFR-alpha by c-Met through a ras- and Src-independent mechanism in human bladder cancer. $B M C$ Cancer 11: 139.

Zhu S, Wurdak H, Wang Y, Galkin A, Tao H, Li J, Lyssiotis CA, Yan F, Tu BP, Miraglia L, Walker J, Sun F, Orth A, Schultz PG, Wu X (2009) A genomic screen identifies TYRO3 as a MITF regulator in melanoma. Proc Natl Acad Sci USA 106(40): 17025-17030.

Zwaagstra JC, Guimond A, O'Connor-McCourt MD (2000) Predominant intracellular localization of the type I transforming growth factor-beta receptor and increased nuclear accumulation after growth arrest. Exp Cell Res 258(1): 121-134.

(c) (i) (2) (2) This work is licensed under the Creative Commons (c) ${ }_{\mathrm{BY}} \mathrm{NC}$ SA Attribution-Non-Commercial-Share Alike 4.0 International License. To view a copy of this license, visit http:// creativecommons.org/licenses/by-nc-sa/4.0/

(C) The Author(s) named above 2017

Supplementary Information accompanies this paper on British Journal of Cancer website (http://www.nature.com/bjc) 